\title{
Diversity and Abundance of Ice Nucleating Strains of Pseudomonas syringae in a Freshwater Lake in Virginia, USA
}

\author{
Renée B. Pietsch ${ }^{1}$, Boris A. Vinatzer ${ }^{2}$ and David G. Schmale III ${ }^{2 *}$ \\ ${ }^{1}$ Department of Biological Sciences, Virginia Tech, Blacksburg, VA, USA, ${ }^{2}$ Department of Plant Pathology, Physiology, and \\ Weed Science, Virginia Tech, Blacksburg, VA, USA
}

The bacterium Pseudomonas syringae is found in a variety of terrestrial and aquatic environments. Some strains of $P$. syringae express an ice nucleation protein (hereafter referred to as Ice+) allowing them to catalyze the heterogeneous freezing of water. Though $P$. syringae has been sampled intensively from freshwater sources in France, little is known about the genetic diversity of $P$. syringae in natural aquatic habitats in North America. We collected samples of freshwater from three different depths in Claytor Lake, Virginia, USA between November 2015 and June 2016. Samples were

OPEN ACCESS

Edited by:

Télesphore Sime-Ngando, Centre National de la Recherche Scientifique, France

Reviewed by: Anne Marie Delort, Blaise Pascal University, France Pierre Amato,

Centre National de la Recherche Scientifique, France

*Correspondence: David G. Schmale III dschmale@vt.edu

Specialty section: This article was submitted to

Aquatic Microbiology,

a section of the journal

Frontiers in Microbiology

Received: 24 October 2016

Accepted: 15 February 2017

Published: 09 March 2017

Citation:

Pietsch RB, Vinatzer BA and Schmale DG III (2017) Diversity and Abundance of Ice Nucleating Strains of Pseudomonas syringae in a Freshwater Lake in Virginia, USA.

Front. Microbiol. 8:318 doi: 10.3389/fmicb.2017.00318 plated on non-selective medium (TSA) and on medium selective for Pseudomonas (KBC) and closely related species to estimate the total number of culturable bacteria and of Pseudomonas, respectively. A droplet freezing assay was used to screen colonies for the Ice+ phenotype. Ice+ colonies were then molecularly identified based on the cts (citrate synthase) gene and the 16S rDNA gene. Phylogenetic analysis of cts sequences showed a surprising diversity of phylogenetic subgroups of $P$. syringae. Frequencies of Ice+ isolates on $P$. syringae selective medium ranged from 0 to $15 \%$ per sample with the highest frequency being found in spring. Our work shows that freshwater lakes can be a significant reservoir of Ice+ $P$. syringae. Future work is needed to determine the contribution of $P$. syringae from freshwater lakes to the $P$. syringae populations present in the atmosphere and on plants and, in particular, if freshwater lakes could be an inoculum source of $P$. syringae-caused plant disease outbreaks.

Keywords: ice nucleation, Pseudomonas, Pseudomonas syringae, cts, freshwater bacteria

\section{INTRODUCTION}

Pseudomonas syringae has been studied as a plant pathogen since the early Twentieth century (Elliott, 1951). It is ubiquitous in most terrestrial environments, including agricultural and uncultivated environments, and aquatic environments (Morris et al., 2013). In regard to aquatic environments, the species has been found in rain, snow, clouds, groundwater, streams, and lakes (Morris et al., 2007, 2008; Vaïtilingom et al., 2012; Renard et al., 2016). While most $P$. syringae strains have the genetic potential to be plant pathogens independently of the environment from which they were isolated, only a minority of strains are known crop pathogens (Monteil et al., 2013).

Some $P$. syringae strains are ice nucleation active (INA) allowing the bacterium to catalyze the freezing of water at temperatures much warmer than the temperature at which pure 
water freezes. This activity is due to expression of a lipoglycoprotein, called the INA protein (Cochet and Widehem, 2000). Besides $P$. syringae, a variety of inorganic materials, such as dust and minerals, as well as other bacteria, fungi, and pollen can act as ice nuclei (Murray et al., 2012). Ice nuclei including ice-nucleation active bacteria (hereafter referred to as Ice+), such as $P$. syringae, may even contribute to the formation of precipitation in clouds via initiating the crystal lattice structure of ice (Morris et al., 2011; Moukahel et al., 2015). However, not every strain of $P$. syringae has the gene for the INA protein (Lindow, 1983) and natural environmental conditions that favor the expression of the protein in strains with the gene are poorly understood (Nemecek-Marshall et al., 1993). Cold temperatures and low nutrient media tend to favor expression of the protein, but not all strains are induced in the same manner (Nemecek-Marshall et al., 1993).

Recently, a new classification was proposed for $P$. syringae with at least 13 different phylogroups (Berge et al., 2014). Though some strains have been mainly isolated from certain habitats and not others (for example, from aquatic environments but not from crops), many strains have been found in all environments known to be occupied by $P$. syringae. Even strains that are almost identical at the whole genome level have been isolated from crops as well as from aquatic environments suggesting that at least some $P$. syringae lineages are frequently exchanged between aquatic environments and agricultural environments (Monteil et al., 2016).

How the bacteria move with and through the water cycle is not well understood as well as the active and passive roles the bacteria play in this movement. There is evidence that Ice+ bacteria are preferentially found in certain components of the water cycle, such as snow (Morris et al., 2008; Monteil et al., 2012; Joly et al., 2013), and a laboratory experiment showed Ice+ bacteria may aerosolize at higher efficiency from aquatic environments than Ice- bacteria (Pietsch et al., 2015). These findings may be an indication that Ice + strains of $P$. syringae may be playing an active role in the water cycle. Moreover, Ice+ $P$. syringae may be benefitting from the water cycle as well since the precipitation they induce, may carry bacteria back to nutrient rich environments on the earth surface. This cycle has been described as "bioprecipitation cycle" (Sands et al., 1982; Morris et al., 2014).

Little is known about the relative abundance of $P$. syringae in aquatic environments (Morris et al., 2008). Though studies have been done on distributions of microorganisms in lakes, these have focused on bacterial byproducts in the context of water quality or changes in bacterial communities in response to changes in lake nutrients (McDonough et al., 1986). Lake sediments have also been analyzed for vertical distributions of bacteria (Haglund et al., 2003; Ye et al., 2009). Several studies examined the vertical distribution of bacteria classifying them into broad taxonomic groups (Glöckner et al., 2000; Comeau et al., 2012). Comeau et al. (2012) found $\gamma$-Proteobacteria accounted for approximately $<2 \%$ of the bacteria collected in a lake. The analysis did not classify $\gamma$-Proteobacteria further to determine if any Pseudomonas were present. Concentrations of bacteria were not determined, but the relative proportion of different types of bacteria changed with depth from 2 to $60 \mathrm{~m}$ as well as differing by sampling season (Comeau et al., 2012). To our knowledge, concentration gradients of Ice + Pseudomonas syringae across the water column have not been examined.

The overall goal of this study was to examine the relative abundance of Ice + strains of $P$. syringae in a large freshwater lake in Virginia, USA. The specific objectives of this study were to: (1) examine the frequency of $P$. syringae within the lake, (2) determine the relative proportion of Ice+ colonies of Pseudomonas in the lake, and (3) examine the phylogenetic relationship within and among strains of $P$. syringae collected from the lake. This research has applications in understanding how P. syringae is distributed in natural bodies of water, and may work toward greater understanding of the potential for a lake to release aerosolized Ice + bacteria into the atmosphere.

\section{METHODS AND MATERIALS}

\section{Sample Collection}

Samples were collected from Claytor Lake, VA, USA on nine different calendar dates. Fall/winter sampling days were: 5 November 2015, 18 November 2015, 16 December 2015, 21 January 2016, and 4 February 2016. Spring sampling days were: 2 May 2016, 16 May 2016, 25 May 2016, and 7 June 2016. Van Dorn (3.2 L) (Wildco, Yulee, Florida, USA) water samplers were used to collect samples of lake water off the side of a kayak. For each sample, the time, GPS coordinates, and water temperature were recorded (Table 2). The samples were taken from four different locations selected to provide a variety of location types and within a reasonable rowing distance from the adjacent beach where the kayak was launched; (1) deep water in the middle of the lake, (2) shallow water near the mouth of an inlet, (3) shallow water in the inlet, (4) the mouth of a boat launch inlet. Samples were collected at the surface of the water at locations 2-4. At location 1 , samples were collected at the water surface, at 4.6 and at $9.1 \mathrm{~m}$. Two Van Dorn samplers were used to collect the

TABLE 1 | Five sampling dates with the number of 3.2 Liter water samples collected from Claytor Lake, VA with a Van Dorn sampler at each location.

\begin{tabular}{|c|c|c|c|c|c|c|c|}
\hline Date & Location & Location & Location & Location & Location & Location & Total \\
\hline & 1 surface & $14.2 \mathrm{~m}$ & $19.1 \mathrm{~m}$ & 2 & 3 & 4 & \\
\hline 5-Nov-15 & 1 & 0 & 0 & 1 & 1 & 1 & 4 \\
\hline 18-Nov-15 & 3 & 0 & 0 & 3 & 0 & 1 & 7 \\
\hline 16-Dec-15 & 3 & 0 & 0 & 3 & 0 & 0 & 6 \\
\hline 21-Jan-16 & 3 & 3 & 1 & 0 & 0 & 0 & 7 \\
\hline 4-Feb-16 & 3 & 3 & 1 & 0 & 0 & 0 & 7 \\
\hline 2-May-16 & 3 & 3 & 1 & 0 & 0 & 0 & 7 \\
\hline 16-May-16 & 3 & 3 & 3 & 0 & 0 & 0 & 9 \\
\hline 25-May-16 & 3 & 3 & 3 & 0 & 0 & 0 & 9 \\
\hline 2-Jun-16 & 3 & 3 & 3 & 0 & 0 & 0 & 9 \\
\hline Total & 25 & 18 & 12 & 7 & 1 & 2 & 65 \\
\hline
\end{tabular}

All locations were collected at the water surface, except location 1 where samples were collected at the surface, $4.6 \mathrm{~m}$ depth, and $9.1 \mathrm{~m}$ depth. Each sample was collected with a 3.2 Liter Van Dorn sampler. See Table 1 for GPS coordinates. 
surface and $4.6 \mathrm{~m}$ samples simultaneously in location 1 . Table 1 shows the number of samples taken at each location on each sampling day.

\section{Processing of Samples for Culturable Bacteria}

The lake water samples were placed on ice in a cooler immediately following collection, and transported back to the laboratory for analysis. In the laboratory, $1 \mathrm{~L}$ of each sample was filtered on to $0.2 \mu \mathrm{m}$ porosity nitrocellulose filters. The filters were placed in $5 \mathrm{~mL}$ of the filtrate for 10 min with a stir bar to resuspend the bacteria at a $200 \mathrm{X}$ concentration. King's medium B modified with cephalexin $(80 \mathrm{mg} / \mathrm{L})$, cycloheximide $(200 \mathrm{mg} / \mathrm{L})$, and boric acid $(1,500 \mathrm{mg} / \mathrm{L})$ (KBC) (Mohan and Schaad, 1987), selective for Pseudomonas, was used to plate 200 $\mu \mathrm{L}$ of the suspension, with three replicates per suspension. The filtrate was also used to make a $2 \mathrm{X}$ concentration, which was plated onto $10 \%$ tryptic soy agar (TSA) to obtain counts of culturable bacteria which grow on TSA. We define culturable as any bacteria that grew on a given media under environmental conditions of $\sim 20^{\circ} \mathrm{C}$. The plates were incubated for $48-72 \mathrm{~h}$ at ambient room temperature $\left(\sim 20^{\circ} \mathrm{C}\right)$ and the colonies were counted.

\section{Ice Nucleation Assays}

Colonies that grew on the KBC plates were selected at random (at least 12 colonies per plate) and transferred to $140 \mu \mathrm{L}$ of water with a sterile toothpick to perform a droplet freezing assay. The samples were stored at $4^{\circ} \mathrm{C}$ for $24 \mathrm{~h}$. Two droplets of $12 \mu \mathrm{L}$ of each sample were loaded onto Parafilm ${ }^{\circledR}$ M floating on an Alpha 12 cooling bath (Lauda, New Jersey, USA). Sterile $0.2 \mu \mathrm{m}$ filtered water was used as a negative control. The temperature of the bath was set at $-5^{\circ} \mathrm{C}$ during loading of the samples, and was then lowered to $-12^{\circ}$ in $1^{\circ} \mathrm{C}$ increments. The temperature at which each of the droplets froze was recorded. Strains for which both droplets froze were selected for further analysis.

\section{Sequence-Assisted Identification of Bacteria}

DNA was extracted from cultures using a Puregene Yeast/Bacteria Kit B (Qiagen \#1042607) and a BioSprint15 DNA Plant Kit (Qiagen \#941517) following manufacturer's protocols. PCR was conducted using a Mastercycler ep Gradient $S$ thermocycler (Eppendorf, New York, USA) with the extracted DNA using primers (forward: 5' CCC GTC GAG CTG CCA ATW CTG A 3', reverse: 5' ATC TCG CAC GGS GTR TTG AAC ATC $3^{\prime}$ ) for the citrate synthase (cts) housekeeping gene to identify colonies of $P$. syringae and related species. A $1 \%$ TBE Ethidium Bromide gel was used to visualize products from the PCR reaction. Samples that did not produce a product specific for $P$. syringae were subjected to PCR with $16 \mathrm{~S}$ primers (518 forward: 5' CCA GCA GCC GCG GTA ATA CG 3', 1,491 reverse: $5^{\prime}$ ATC GGY TAC CTT GTT ACG ACT TC 3'). PCR was performed with GoTaq ${ }^{\circledR}$ Green Master Mix (Promega M712) under the following parameters: $1 \mathrm{x}$ cycle denaturation $95^{\circ} \mathrm{C}$ for $10 \mathrm{~min}, 5 \mathrm{x}$ cycle denaturation 95 for $1 \mathrm{~min}$, annealing $53^{\circ} \mathrm{C}$ for $30 \mathrm{~s}$, extension $72^{\circ} \mathrm{C} 1 \mathrm{~min} 40 \mathrm{~s}, 25 \mathrm{x}$ cycle $94^{\circ} \mathrm{C} 30 \mathrm{~s}$, $53^{\circ} \mathrm{C} 20 \mathrm{~s}, 72^{\circ} \mathrm{C} 1 \mathrm{~min}, 1 \mathrm{x}$ cycle $72^{\circ} \mathrm{C} 10 \mathrm{~min}$, hold $\left.4^{\circ} \mathrm{C}\right)$. The samples were purified using ExoI/rSAP prior to sequencing (AB1 3730x1 DNA Sequencer, Eton Biosciences, 104 T.W. Alexander Drive, Bldg 4A, RTP, NC 27709, USA). The sequences from 16S primers were used to search GenBank (http://www.ncbi.nlm.nih. gov/blast) using the Blastn algorithm to identify the sequence with the closest match. The sequences from cts primers along with 38 reference strains of $P$. syringae (Berge et al., 2014) were aligned using the Clustal W method and a phylogenetic tree was constructed selecting the neighbor-joining algorithm in MEGA7 with 1,000 bootstrap replicates.

\section{Statistical Analyses}

Statistical analyses were conducted in R (Version 3.3.1, http:// www.r-project.org). Because data were not normally distributed, non-parametric Kruskal-Wallis rank sum tests, were used to test for significant differences $(P<0.05)$ between percent of Ice + strains between colony forming units (CFU) of samples at different depths $(n=55)$ and locations $(n=17)$. A Wilcoxon rank sum test for non-parametric data was used to compare between percent of Ice + strains in fall/winter and spring collections $(n=66)$.

\section{RESULTS}

\section{Concentration of Bacteria}

The concentration of bacteria (CFU Liter ${ }^{-1}$ ) and Pseudomonas in lake water was estimated from the counts of colonies on TSA and KBC media, respectively (Table 2). Between 0 and $30 \%$ of the bacteria cultured on TSA were Pseudomonas. In 17 of 66 samples, between 1 and $10 \%$ of the strains tested were Ice + , and in 16 of 66 samples $>10 \%$ of the strains tested were Ice+. The concentration of colonies that grew on KBC media (Pseudomonas) for each sampling location for each day of collection showed considerable variation across all days and across all sampling locations. Figure 1 shows box plots of the concentration (CFU Liter ${ }^{-1}$ ) of Pseudomonas from all locations that grew on $\mathrm{KBC}$ media for all days of sampling, indicating that Pseudomonas was consistently found throughout Claytor Lake. However, the mean concentration for each collection day varied dramatically from a low of 110 CFU Liter ${ }^{-1}$ on 5 November 2015 to 16,240 CFU Liter ${ }^{-1}$ on 25 May 2016.

\section{Ice+ Pseudomonas Strains}

The 2,750 colonies from KBC media were tested for the Ice+ phenotype with an ice nucleation assay. The freezing temperature between $-5^{\circ} \mathrm{C}$ and $-12^{\circ} \mathrm{C}$ was recorded for each droplet, and $58 \%$ froze at $-5^{\circ} \mathrm{C}, 14 \%$ at $-6^{\circ} \mathrm{C}, 4 \%$ at $-7^{\circ} \mathrm{C}, 3 \%$ at $-8^{\circ} \mathrm{C}$, $4 \%$ at $-9^{\circ} \mathrm{C}, 7 \%$ at $-10^{\circ} \mathrm{C}, 5 \%$ at $-11^{\circ} \mathrm{C}$, and $6 \%$ at $-12^{\circ} \mathrm{C}$. The percent of colonies for which both tested droplets froze (Table 3, Figure 2) was between 0 and $15 \%$ of the colonies on all sampling days. A total of 176 strains was Ice+ (Table 4). A majority of the Ice + samples produced a product with the cts primer pair indicating they were $P$. syringae (Table 4). The percentage of Ice + Pseudomonas colonies that did not produce a cts PCR product from the fall/winter collections (therefore, likely not $P$. syringae) was between 15 and $20 \%$ on each day of sampling 
TABLE 2 | Data for each 3.2 Liter water sample collected from Claytor Lake, VA with a Van Dorn sampler including sampling date, ambient air temperature $\left({ }^{\circ} \mathrm{F}\right)$, water temperature at sampling location $\left({ }^{\circ} \mathrm{F}\right)$, sampling depth, GPS location, Mean CFU Liter ${ }^{-1}$ of Pseudomonas grown on KBC media based on three plates, mean CFU Liter ${ }^{-1}$ of total bacteria on TSA media based on three plates, percent Pseudomonas grown on KBC media, percent of Ice+ strains from colonies grown on KBC media.

\begin{tabular}{|c|c|c|c|c|c|c|c|c|c|}
\hline $\begin{array}{l}\text { Sampling } \\
\text { date }\end{array}$ & $\begin{array}{l}\text { Air temp } \\
\quad\left({ }^{\circ} \mathrm{C}\right)\end{array}$ & $\begin{array}{l}\text { Water temp } \\
\quad\left({ }^{\circ} \mathrm{C}\right)\end{array}$ & $\begin{array}{l}\text { Location } \\
\text { area }\end{array}$ & $\begin{array}{l}\text { Sample } \\
\text { depth }\end{array}$ & GPS coordinates & $\begin{array}{c}\text { Mean CFU } \\
\text { liter }{ }^{-1} \text { on KBC } \\
\text { media } \pm \text { st. dev. }\end{array}$ & $\begin{array}{l}\text { Mean CFU Liter }{ }^{-1} \text { on } \\
\text { TSA media } \pm \text { st. dev. }\end{array}$ & $\begin{array}{l}\text { Ratio of CFU on } \\
\text { KBC:TSA (\%) }\end{array}$ & $\begin{array}{l}\text { \%lce+ } \\
\text { colonies }\end{array}$ \\
\hline 5-Nov-15 & 18.9 & n.d. & 2 & Surface & $37.051167,-80.623722$ & $100 \pm 25$ & n.d. & n.d. & 43.75 \\
\hline 5-Nov-15 & 18.9 & n.d. & 3 & Surface & $37.05208,-80.624204$ & $108 \pm 104$ & n.d. & n.d. & 26.32 \\
\hline 5-Nov-15 & 18.9 & n.d. & 1 & Surface & $37.052242,-80.617239$ & $42 \pm 29$ & n.d. & n.d. & 0.00 \\
\hline 18-Nov-15 & 11.1 & n.d. & 2 & Surface & $37.050904,-80.623690$ & $367 \pm 138$ & $9.42 \mathrm{E}+04 \pm 629$ & 0.39 & 0.00 \\
\hline 18-Nov-15 & 11.1 & n.d. & 2 & Surface & $37.051063,-80.623709$ & $208 \pm 166$ & $8.50 \mathrm{E}+04 \pm 444$ & 0.25 & 5.56 \\
\hline 18-Nov-15 & 11.1 & n.d. & 2 & Surface & $37.051246,-80.623684$ & $50 \pm 43$ & $2.75 \mathrm{E}+04 \pm 152$ & 0.18 & 0.00 \\
\hline 18-Nov-15 & 11.1 & n.d. & 1 & Surface & $37.051911,-80.619642$ & $283 \pm 159$ & $8.42 \mathrm{E}+04 \pm 603$ & 0.34 & 5.88 \\
\hline 18-Nov-15 & 11.1 & n.d. & 1 & Surface & $37.052095,-80.619428$ & $442 \pm 101$ & $7.92 \mathrm{E}+04 \pm 506$ & 0.56 & 20.69 \\
\hline 16-Dec-15 & 8.9 & 9.4 & 2 & Surface & $37.051368,-80.623841$ & $3,500 \pm 87$ & $6.20 \mathrm{E}+05 \pm 826$ & 0.57 & 10.29 \\
\hline 16-Dec-15 & 8.9 & 9.1 & 1 & Surface & $37.052293,-80.619069$ & $1,700 \pm 400$ & $1.11 \mathrm{E}+05 \pm 311$ & 1.53 & 14.71 \\
\hline 16-Dec-15 & 8.9 & 9.0 & 1 & Surface & $37.052179,-80.619059$ & $1,167 \pm 161$ & $1.68 \mathrm{E}+05 \pm 247$ & 0.69 & 16.67 \\
\hline 16-Dec-15 & 8.9 & 9.4 & 1 & Surface & $37.052249,-80.619043$ & $400 \pm 115$ & $7.08 \mathrm{E}+04 \pm 138$ & 0.57 & 13.46 \\
\hline 21-Jan-16 & -1.1 & 40.7 & 1 & $4.2 \mathrm{~m}$ & $37.0515635,-80.6169486$ & $717 \pm 188$ & $1.00 \mathrm{E}+05 \pm 50$ & 0.72 & 10.87 \\
\hline 21-Jan-16 & -1.1 & 4.6 & 1 & Surface & $37.0509283,-80.6169794$ & $583 \pm 76$ & $9.33 \mathrm{E}+04 \pm 454$ & 0.63 & 4.84 \\
\hline 21-Jan-16 & -1.1 & 4.6 & 1 & $4.2 \mathrm{~m}$ & $37.0522448,-80.6170897$ & $967 \pm 151$ & $2.19 \mathrm{E}+05 \pm 601$ & 0.44 & 10.29 \\
\hline 21-Jan-16 & -1.1 & 4.6 & 1 & Surface & $37.0522448,-80.6170897$ & $683 \pm 104$ & $1.41 \mathrm{E}+05 \pm 322$ & 0.49 & 8.33 \\
\hline 21-Jan-16 & -1.1 & 4.2 & 1 & $4.2 \mathrm{~m}$ & $37.0520847,-80.6169546$ & $700 \pm 150$ & $2.14 \mathrm{E}+05 \pm 454$ & 0.33 & 12.50 \\
\hline 21-Jan-16 & -1.1 & 4.6 & 1 & Surface & $37.0517267,-80.6169077$ & $692 \pm 161$ & $1.10 \mathrm{E}+05 \pm 402$ & 0.63 & 9.62 \\
\hline 4-Feb-16 & 5.6 & 2.0 & 1 & $9.1 \mathrm{~m}$ & $37.0522846,-80.6189418$ & $9,092 \pm 210$ & $2.79 \mathrm{E}+06 \pm 1,760$ & 0.33 & 0.00 \\
\hline 2-May-16 & 22.8 & 20.9 & 1 & Surface & n.d. & $183 \pm 80$ & $1,015,833 \pm 1,420$ & 0.02 & 0.00 \\
\hline 2-May-16 & 22.8 & 20.3 & 1 & Surface & n.d. & $67 \pm 29$ & $487,500 \pm 180$ & 0.01 & 0.00 \\
\hline 2-May-16 & 22.8 & 19.6 & 1 & $4.2 \mathrm{~m}$ & n.d. & $217 \pm 101$ & $647,500 \pm 66$ & 0.03 & 8.00 \\
\hline 2-May-16 & 22.8 & 20.6 & 1 & Surface & n.d. & $175 \pm 66$ & $904,167 \pm 521$ & 0.02 & 0.00 \\
\hline 2-May-16 & 22.8 & 19.5 & 1 & $4.2 \mathrm{~m}$ & n.d. & $542 \pm 38$ & $675,000 \pm 541$ & 0.08 & 0.00 \\
\hline 2-May-16 & 22.8 & 19.9 & 1 & $4.2 \mathrm{~m}$ & n.d. & $208 \pm 38$ & $655,833 \pm 1,250$ & 0.03 & 4.16 \\
\hline 2-May-16 & 22.8 & n.d. & 1 & $9.1 \mathrm{~m}$ & n.d. & $83 \pm 38$ & $270,000 \pm 426$ & 0.03 & 0.00 \\
\hline 16-May-16 & 10 & 17.7 & 1 & Surface & n.d. & $42,200 \pm 5,495$ & $410,000 \pm 303$ & 10.29 & 0.00 \\
\hline 16-May-16 & 10 & 18.9 & 1 & $4.2 \mathrm{~m}$ & n.d. & $92 \pm 63$ & $1,227,500 \pm 180$ & 0.01 & 9.09 \\
\hline 16-May-16 & 10 & 18.9 & 1 & Surface & n.d. & $1,225 \pm 229$ & $898,333 \pm 440$ & 0.14 & 0.00 \\
\hline 16-May-16 & 10 & 18.9 & 1 & $4.2 \mathrm{~m}$ & n.d. & $183 \pm 52$ & $889,167 \pm 1,620$ & 0.02 & 4.34 \\
\hline 16-May-16 & 10 & 18.9 & 1 & $9.1 \mathrm{~m}$ & $37.0522500,-80.6190833$ & $8 \pm 14$ & $1,052,500 \pm 2,870$ & 0.001 & 0.00 \\
\hline 16-May-16 & 10 & 18.9 & 1 & $9.1 \mathrm{~m}$ & $37.0522500,-80.6190833$ & $2,908 \pm 153$ & $1,018,333 \pm 3,570$ & 0.29 & 0.00 \\
\hline 16-May-16 & 10 & 18.9 & 1 & Surface & $37.0522500,-80.6190278$ & $2,433 \pm 95$ & $1,140,833 \pm 2,040$ & 0.21 & 0.00 \\
\hline 16-May-16 & 10 & 18.9 & 1 & $4.2 \mathrm{~m}$ & $37.0522500,-80.6190278$ & $42 \pm 14$ & $960,833 \pm 1,030$ & 0.004 & 0.00 \\
\hline
\end{tabular}


TABLE 2 | Continued

\begin{tabular}{|c|c|c|c|c|c|c|c|c|c|}
\hline $\begin{array}{l}\text { Sampling } \\
\text { date }\end{array}$ & $\begin{array}{l}\text { Air temp } \\
\left({ }^{\circ} \mathrm{C}\right)\end{array}$ & $\begin{array}{l}\text { Water temp } \\
\left({ }^{\circ} \mathrm{C}\right)\end{array}$ & $\begin{array}{c}\text { Location } \\
\text { area }\end{array}$ & $\begin{array}{l}\text { Sample } \\
\text { depth }\end{array}$ & GPS coordinates & $\begin{array}{c}\text { Mean CFU } \\
\text { liter } \\
\text { media } \pm \text { on KB. dev. }\end{array}$ & $\begin{array}{l}\text { Mean CFU Liter }{ }^{-1} \text { on } \\
\text { TSA media } \pm \text { st. dev. }\end{array}$ & $\begin{array}{c}\text { Ratio of CFU on } \\
\text { KBC:TSA (\%) }\end{array}$ & $\begin{array}{c}\text { \%lce+ } \\
\text { colonies }\end{array}$ \\
\hline 25-May-16 & 18.9 & 19.7 & 1 & Surface & n.d. & $57,000 \pm 7,632$ & $188,333 \pm 1,180$ & 30.27 & 0.00 \\
\hline 25-May-16 & 18.9 & 18.8 & 1 & $4.2 \mathrm{~m}$ & n.d. & $6,775 \pm 1,233$ & $415,000 \pm 557$ & 1.63 & 0.00 \\
\hline 25-May-16 & 18.9 & 19.9 & 1 & Surface & n.d. & $1,358 \pm 232$ & $385,833 \pm 313$ & 0.35 & 0.00 \\
\hline 25-May-16 & 18.9 & n.d. & 1 & Surface & n.d. & $6,025 \pm 876$ & $407,500 \pm 1,100$ & 1.48 & 0.00 \\
\hline 25-May-16 & 18.9 & n.d. & 1 & $4.2 \mathrm{~m}$ & n.d. & $500 \pm 152$ & $700,833,525$ & 0.07 & 0.00 \\
\hline 25-May-16 & 18.9 & n.d. & 1 & $9.1 \mathrm{~m}$ & n.d. & $1,142 \pm 213$ & $772,500 \pm 3,830$ & 0.15 & 0.00 \\
\hline 25-May-16 & 18.9 & n.d. & 1 & $9.1 \mathrm{~m}$ & n.d. & $39,917 \pm 3,894$ & $192,500 \pm 90$ & 20.74 & 0.00 \\
\hline 25-May-16 & 18.9 & n.d. & 1 & $9.1 \mathrm{~m}$ & n.d. & $31,408 \pm 4,367$ & $246,667 \pm 32$ & 12.73 & 0.00 \\
\hline 7-Jun-16 & 21.1 & 25.0 & 1 & Surface & $37.0525921667,-80.617109333$ & $4,167 \pm 216$ & $119,167 \pm 191$ & 3.50 & 0.00 \\
\hline 7-Jun-16 & 21.1 & 24.9 & 1 & $4.2 \mathrm{~m}$ & $37.0525921667,-80.617109333$ & $42 \pm 52$ & $113,333 \pm 201$ & 0.04 & 0.00 \\
\hline 7-Jun-16 & 21.1 & 24.8 & 1 & $9.1 \mathrm{~m}$ & n.d. & $17 \pm 29$ & $192,500,1,040$ & 0.01 & 0.00 \\
\hline 7-Jun-16 & 21.1 & 25.2 & 1 & Surface 3 & $37.0523113333,-80.6172223333$ & $142 \pm 14$ & $139,167 \pm 227$ & 0.10 & 0.00 \\
\hline 7-Jun-16 & 21.1 & 25.0 & 1 & $4.2 \mathrm{~m} \quad 3$ & $37.0523113333,-80.6172223333$ & $8 \pm 14$ & $140,000 \pm 152$ & 0.01 & 0.00 \\
\hline
\end{tabular}

n.d. = no data.

with the exception of 4 February 2016 for which $47 \%$ of the Ice + colonies were not $P$. syringae. The spring collections were not considered because the sample size of Ice+ strains was too small to obtain an accurate percentage. The $16 \mathrm{~S}$ sequence results confirmed that these colonies were not $P$. syringae; they were identified as Xanthomonas, P. fragi, P. fluorescens, P. viridiflava, and $P$. plecoglossicida.

\section{Phylogenetic Analysis of Pseudomonas syringae Strains}

A phylogenetic tree was constructed with all of the samples that produced a cts product as well as 38 reference strains representing 13 phylogroups of $P$. syringae (Berge et al., 2014; Figure 3 ). The strains from Claytor Lake were compared to the 13 phylogroups with all groupings having bootstrap values of 84 or higher. The samples from Claytor Lake represent six phylogroups groups: 2, 3, 4, 7, 9, and 13. The 5 November 2015 collection showed less diversity, with all isolates belonging to phylogroup 2 and one isolate belonging to phylogroup 3 . This is the only sample collection that included samples from location 3 and 4 . Thus, all isolates from these two locations are in phylogroup 2 and 3.

\section{Non-Pseudomonas syringae Strains}

The colonies that did not produce a cts product were sequenced with $16 \mathrm{~S}$ primers and BLAST results showed they were all Pseudomonas with the exception of three colonies which represented members of the genus Xanthomonas. The BLAST results for the Pseudomonas colonies that were not $P$. syringae showed a $100 \%$ match with $P$. fragi, $P$. fluorescens, $P$. viridiflava, and $P$. plecoglossicida. Additional phylogenetic analyses are needed to confirm these taxonomic assignments, which is beyond the scope of this study.

\section{Statistical Analyses}

There was no significant difference between the CFU on $\mathrm{KBC}$ media at different depths $(P=0.913)$ or locations $(P=$ $0.567)$. There was a significant difference between the percent of Ice+ strains in the fall collections and spring collections $(P<0.001)$.

\section{DISCUSSION}

Little is known about the abundance of Pseudomonas in aquatic environments. Here, we show the distribution of Pseudomonas in a freshwater lake, examining the concentration across sampling dates in two seasons and at three depths. Pseudomonas colonies were obtained from every sample collected on every day of sampling, indicating they are ubiquitous throughout Claytor Lake. Variation was observed in the concentration of Pseudomonas at different sampling locations and across different sampling days. The concentrations of Pseudomonas collected ranged widely, between 25 and $5.7 \times 10^{5} \mathrm{CFU}$ Liter $^{-1}$ indicating a non-uniform distribution. Within each day of sampling there was variation between sampling locations. The location with the highest concentration varied from day to day, suggesting that bacteria continually move and mix and/or reproduce and die at different rates at different locations depending on local environmental conditions. Comparisons to previous concentrations are limited due to a lack of reported concentrations of Pseudomonas in freshwater lakes. However, 


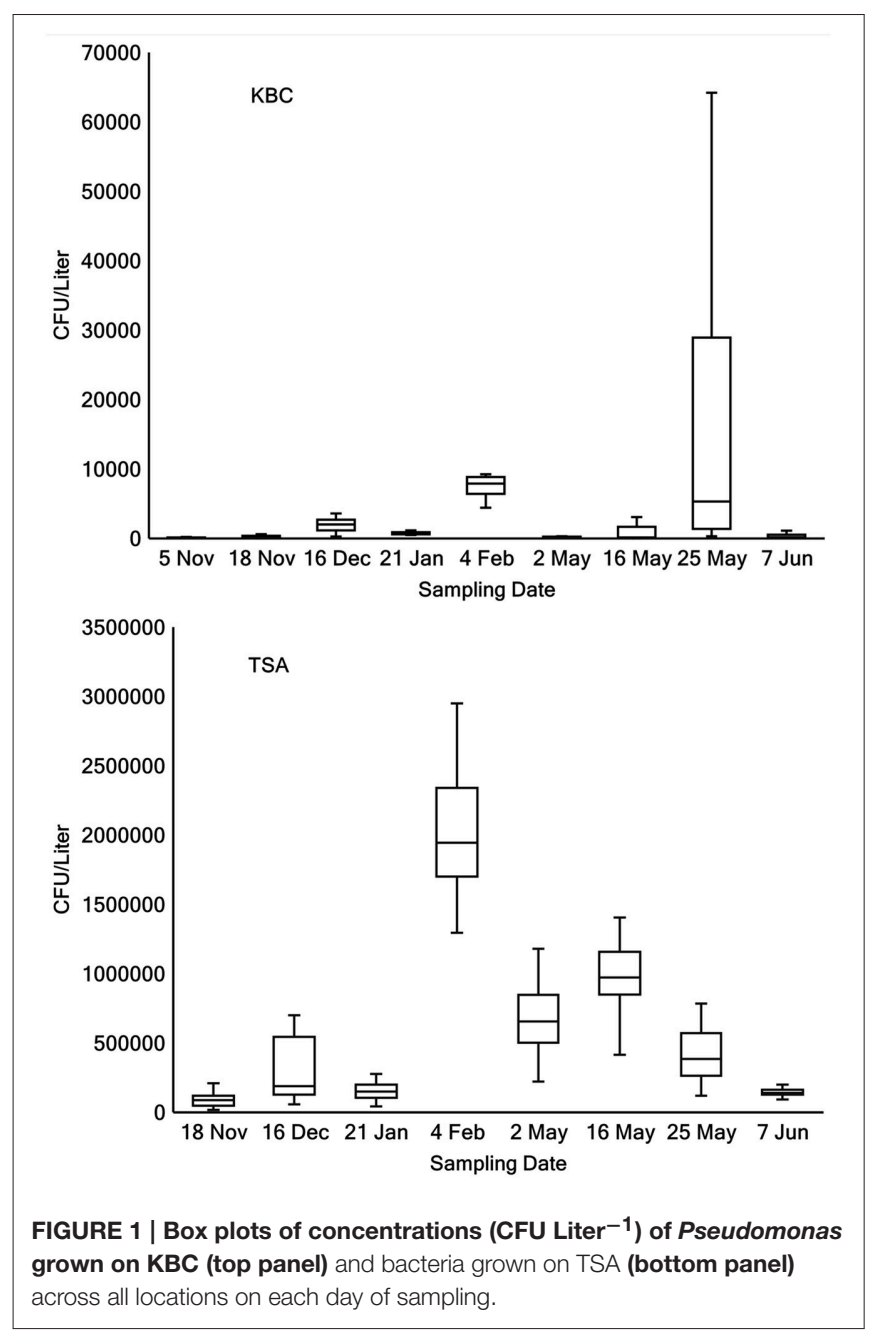

TABLE 3 | The number of Pseudomonas colonies from the KBC media that froze for each day of sampling using an ice nucleation assay.

\begin{tabular}{lccc}
\hline Sampling date & $\begin{array}{c}\text { Number of } \\
\text { Ice+ colonies }\end{array}$ & $\begin{array}{c}\text { Number of colonies } \\
\text { assayed }\end{array}$ & $\begin{array}{c}\% \text { of colonies } \\
\text { Ice+ }\end{array}$ \\
\hline 5 November 2015 & 24 & 160 & 15.0 \\
18 November 2015 & 33 & 220 & 15.0 \\
16 December 2015 & 51 & 384 & 13.3 \\
21 January 2016 & 37 & 384 & 9.6 \\
4 February 2016 & 26 & 384 & 6.8 \\
2 May 2016 & 3 & 177 & 1.7 \\
16 May 2016 & 2 & 283 & 0.7 \\
25 May 2016 & 0 & 476 & 0.0 \\
7 June 2016 & 1 & 282 & 0.4 \\
\hline
\end{tabular}

Morris et al. (2008) sampled four freshwater lakes and found similar concentrations of Pseudomonas syringae between 130 and $1 \times 10^{4}$ CFU Liter $^{-1}$.

The relative abundance of Pseudomonas ranged between 0 and $30 \%$ of the total culturable bacteria (based on counts from TSA), with most collections between 0.1 and $1.5 \%$, indicating

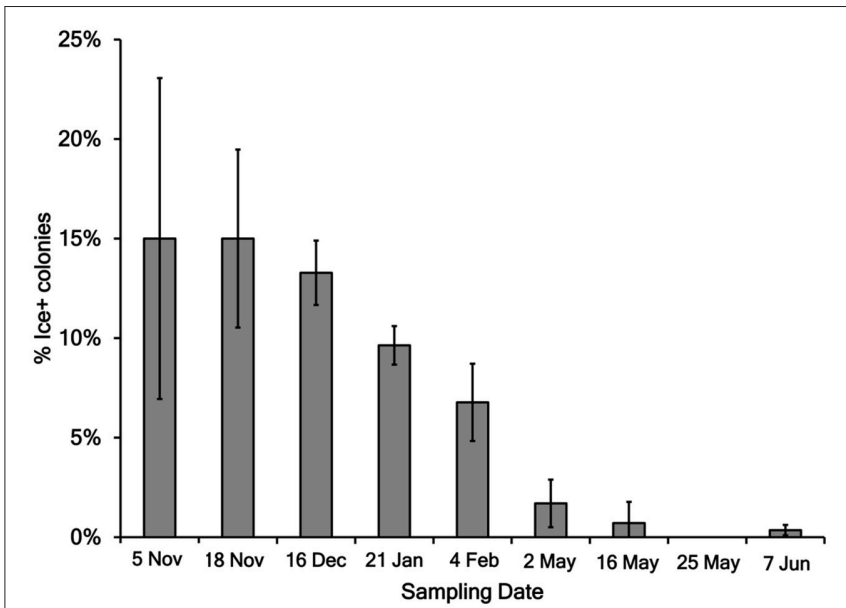

FIGURE 2 | Percent of Ice+ Pseudomonas colonies grown on KBC media for each day of sampling. Error bars are standard error of the water samples on each collection day. The following number of droplets were tested for each collection day: 5 November $2015=160$, 18 November $2015=220$, 16 December $2015=384,21$ January $2016=384$, 4 February $2016=384$, 2 May $2016=177,16$ May $2016=283,25$ May $2016=476$, and 7 June $2016=282$.

Pseudomonas was a small minority of the bacteria present. The concentration of Pseudomonas appears to be variable and subject to change day to day and even in different locations on the same day. Previous studies examining the relative abundances of bacteria in freshwater lakes found between 5 and $10 \%$ of the bacteria sampled were $\gamma$-Proteobacteria (which includes Pseudomonas; Hiorns et al., 1997; Tamaki et al., 2005; Briée et al., 2007; Wang et al., 2012).

There was no significant difference in the concentration of Pseudomonas at different depths $(P=0.913)$ or locations $(P=$ $0.567)$. The first 2 days of sampling five different locations in the lake were sampled, but with this finding of non-significance one location was chosen for the remaining 7 days of sampling. In general, more variation was seen in the concentrations of CFU on $\mathrm{KBC}$ media in the spring collections since both, the highest and lowest concentrations, were obtained in the spring collections. The total bacteria count on non-selective TSA medium did not show as much variation between the two seasons of collection, suggesting that Pseudomonas is likely more subject to variation than the bacteria cultured on TSA.

Between 0 and $15 \%$ of the Pseudomonas colonies were Ice+ on each sampling day, indicating Ice+ strains are consistently present throughout Claytor Lake. The Ice+ colonies were not evenly distributed across samples on a given day. Some collections did not have any Ice+ colonies and others had up to 50\%. Joly et al. (2013) sampled cloud water for Ice+ Pseudomonas and found $12 \%$ of the strains tested were Ice+. In regard to ice nucleation activity, the populations of Pseudomonas in Claytor Lake and in clouds are similar, though different methods were used to test for ice nucleation activity in these different environments. Strains of Pseudomonas may be moving between clouds and freshwater lakes via rain and aerosolization (Morris et al., 2014), but experiments to track specific strains 
TABLE 4 | Freezing temperatures of replicates 1 and 2 for each strain tested for ice nucleation activity, and GenBank accession numbers for cts sequences for strains of $P$. syringae.

Strain ID Freezing temp Freezing temp Sequence ID of droplet \#1 of droplet \#2 $\begin{array}{ll}\left.{ }^{\circ} \mathrm{C}\right) & \left({ }^{\circ} \mathrm{C}\right)\end{array}$

\begin{tabular}{|c|c|c|c|c|}
\hline CLA 1 & -8 & -8 & P. syringae & KY629082 \\
\hline CLA 2 & -5 & -5 & P. syringae & KY629083 \\
\hline CLA 3 & -5 & -5 & P. syringae & KY629084 \\
\hline CLA 4 & -5 & -5 & P. syringae & KY629085 \\
\hline CLA 5 & -5 & -5 & P. syringae & KY629086 \\
\hline CLA 6 & -5 & -5 & P. syringae & KY629087 \\
\hline CLA 7 & -5 & -5 & P. syringae & KY629088 \\
\hline CLA 8 & -5 & -5 & P. syringae & KY629089 \\
\hline CLA 9 & -6 & -5 & P. fragi & - \\
\hline CLA 10 & -5 & -5 & P. syringae & KY629090 \\
\hline CLA 11 & -5 & -5 & P. syringae & KY629091 \\
\hline CLA 12 & -5 & -5 & P. syringae & KY629092 \\
\hline CLA 13 & -11 & -10 & P. syringae & KY629093 \\
\hline CLA 14 & -5 & -5 & P. syringae & KY629094 \\
\hline CLA 15 & -5 & -5 & P. syringae & KY629095 \\
\hline CLA 16 & -5 & -5 & P. syringae & KY629096 \\
\hline CLA 17 & -7 & -7 & P. syringae & KY629097 \\
\hline CLA 18 & -10 & -9 & P. syringae & KY629098 \\
\hline CLA 19 & -5 & -5 & P. syringae & KY629099 \\
\hline CLA 20 & -7 & -9 & Xanthomonas & - \\
\hline CLA 21 & -5 & -5 & P. syringae & KY629100 \\
\hline CLA 22 & -10 & -11 & P. syringae & KY629101/102 \\
\hline CLA 23 & -11 & -11 & Xanthomonas & - \\
\hline CLA 24 & -11 & -12 & Xanthomonas & - \\
\hline CLB1 & -5 & -5 & P. syringae & KY629103 \\
\hline CLB2 & -5 & -5 & P. syringae & KY629104 \\
\hline CLB3 & -6 & -6 & P. syringae & KY629105 \\
\hline CLB4 & -5 & -5 & P. syringae & KY629106 \\
\hline CLB5 & -6 & -7 & P. syringae & KY629107 \\
\hline CLB6 & -5 & -6 & P. syringae & KY629108 \\
\hline CLB7 & -10 & -10 & P. syringae & KY629109 \\
\hline CLB8 & -5 & -5 & P. syringae & KY629110 \\
\hline CLB9 & -5 & -5 & P. syringae & KY629111 \\
\hline CLB10 & -8 & -11 & P. fluorescens & - \\
\hline CLB11 & -5 & -5 & P. syringae & KY629112 \\
\hline CLB12 & -5 & -5 & P. syringae & KY629113 \\
\hline CLB13 & -7 & -7 & P. syringae & KY629114 \\
\hline CLB14 & -5 & -5 & P. fragi & - \\
\hline CLB15 & -5 & -5 & P. syringae & KY629115 \\
\hline CLB16 & -5 & -5 & P. syringae & KY629116 \\
\hline CLB17 & -5 & -5 & P. syringae & KY629117 \\
\hline CLB18 & -5 & -5 & P. syringae & KY629118 \\
\hline CLB19 & -5 & -5 & P. syringae & KY629119 \\
\hline CLB2O & -5 & -5 & P. syringae & KY629120 \\
\hline CLB21 & -5 & -5 & P. syringae & KY629121 \\
\hline CLB22 & -5 & -5 & P. syringae & KY629122 \\
\hline CLB23 & -5 & -5 & P. syringae & KY629123 \\
\hline
\end{tabular}

(Continued)
TABLE 4 | Continued

Strain ID Freezing temp Freezing temp Sequence ID Gen Bank \# of droplet \#1 of droplet \#2

$\left({ }^{\circ} \mathrm{C}\right) \quad\left({ }^{\circ} \mathrm{C}\right)$

\begin{tabular}{|c|c|c|c|c|}
\hline CLB24 & -5 & -5 & P. syringae & KY629124 \\
\hline CLB25 & -5 & -5 & P. syringae & - \\
\hline CLB26 & -5 & -5 & P. syringae & KY629125 \\
\hline CLB27 & -11 & -11 & P. syringae & KY629126 \\
\hline CLB28 & -5 & -8 & P. syringae & KY629127 \\
\hline CLB29 & -5 & -5 & P. fluorescens & KY629128 \\
\hline CLB30 & -10 & -7 & P. syringae & KY629129 \\
\hline CLB31 & -5 & -5 & P. fragi & - \\
\hline CLB32 & -11 & -9 & P. fragi & - \\
\hline CLC1 & -5 & -5 & P. syringae & KY629130 \\
\hline CLC2 & -5 & -5 & P. syringae & KY629131 \\
\hline CLC3 & -9 & -9 & P. syringae & KY629132 \\
\hline CLC4 & -5 & -5 & P. syringae & KY629133 \\
\hline CLC5 & -5 & -5 & P. syringae & KY629134 \\
\hline CLC6 & -6 & -12 & P. fluorescens & - \\
\hline $\mathrm{CLC7}$ & -5 & -5 & P. syringae & KY629135 \\
\hline CLC8 & -5 & -6 & P. syringae & KY629136 \\
\hline CLC9 & -5 & -7 & P. syringae & KY629137 \\
\hline CLC10 & -6 & -5 & P. syringae & KY629138 \\
\hline CLC11 & -11 & -10 & P. fragi & - \\
\hline CLC12 & -7 & -5 & P. viridiflava & KY629139 \\
\hline CLC13 & -6 & -5 & P. syringae & KY629140 \\
\hline CLC14 & -6 & -5 & P. syringae & KY629141 \\
\hline CLC15 & -6 & -5 & P. syringae & KY629142 \\
\hline CLC16 & -5 & -5 & P. syringae & KY629143 \\
\hline CLC17 & -6 & -5 & P. syringae & KY629144 \\
\hline CLC18 & -6 & -5 & P. syringae & KY629145 \\
\hline CLC19 & -6 & -5 & Pseudomonas & - \\
\hline CLC20 & -6 & -5 & P. syringae & KY629146 \\
\hline CLC21 & -6 & -8 & P. syringae & KY629147 \\
\hline CLC22 & -6 & -9 & P. syringae & KY629148 \\
\hline CLC23 & -5 & -5 & P. syringae & KY629149 \\
\hline CLC24 & -5 & -5 & P. viridiflava & - \\
\hline CLC25 & -5 & -5 & P. syringae & KY629150 \\
\hline CLC26 & -5 & -5 & P. syringae & KY629151 \\
\hline CLC27 & -5 & -5 & P. syringae & KY629152 \\
\hline CLC28 & -12 & -7 & P. syringae & KY629153 \\
\hline CLC29 & -5 & -6 & P. syringae & KY629154 \\
\hline CLC30 & -5 & -6 & P. syringae & KY629155 \\
\hline CLC31 & -10 & -14 & P. syringae & KY629156 \\
\hline CLC32 & -12 & -13 & Pseudomonas & - \\
\hline CLC33 & -8 & -14 & P. fragi & KY629157 \\
\hline CLC34 & -5 & -6 & P. syringae & KY629158 \\
\hline CLC35 & -12 & -12 & P. fragi & KY629159 \\
\hline CLC36 & -12 & -12 & P. syringae & KY629160 \\
\hline CLC37 & -5 & -6 & P. syringae & KY629161 \\
\hline CLC38 & -5 & -7 & P. syringae & KY629162 \\
\hline CLC39 & -6 & -5 & P. syringae & KY629163 \\
\hline CLC40 & -5 & -5 & P. syringae & KY629164 \\
\hline
\end{tabular}

(Continued) 
TABLE 4 | Continued

\begin{tabular}{|c|c|c|c|c|}
\hline Strain ID & $\begin{array}{l}\text { Freezing temp } \\
\text { of droplet \#1 } \\
\left.\text { ( }{ }^{\circ} \mathrm{C}\right)\end{array}$ & $\begin{array}{l}\text { Freezing temp } \\
\text { of droplet \#2 } \\
\left({ }^{\circ} \mathrm{C}\right)\end{array}$ & Sequence ID & Gen Bank \# \\
\hline CLC41 & -5 & -5 & P. syringae & KY629165 \\
\hline CLC42 & -12 & -7 & P. syringae & KY629166 \\
\hline CLC43 & -6 & -5 & P. viridiflava & - \\
\hline CLC44 & -6 & -5 & P. syringae & KY629167 \\
\hline CLC45 & -6 & -5 & P. syringae & KY629168 \\
\hline CLC46 & -6 & -5 & P. syringae & KY629169 \\
\hline CLC47 & -6 & -5 & P. syringae & KY629170 \\
\hline CLC48 & -11 & -5 & P. syringae & KY629171 \\
\hline CLC49 & -9 & -11 & P. syringae & KY629172 \\
\hline CLC50 & -6 & -5 & P. syringae & KY629173 \\
\hline CLC51 & -12 & -9 & Pseudomonas & - \\
\hline CLD1 & -5 & -5 & P. syringae & KY629174 \\
\hline CLD2 & -5 & -5 & P. syringae & KY629175 \\
\hline CLD3 & -5 & -5 & P. syringae & KY629176 \\
\hline CLD4 & -5 & -5 & P. syringae & KY629177 \\
\hline CLD5 & -5 & -5 & P. syringae & KY629178 \\
\hline CLD6 & -5 & -5 & P. syringae & - \\
\hline CLD7 & -5 & -5 & P. syringae & KY629179 \\
\hline CLD8 & -5 & -5 & P. syringae & KY629180 \\
\hline CLD9 & -12 & -12 & P. syringae & KY629181 \\
\hline CLD10 & -6 & -6 & P. syringae & KY629182 \\
\hline CLD11 & -6 & -6 & P. syringae & KY629183/184 \\
\hline CLD12 & -12 & -9 & P. syringae & - \\
\hline CLD13 & -5 & -5 & P. syringae & KY629185 \\
\hline CLD14 & -5 & -5 & P. fragi & - \\
\hline CLD15 & -5 & -5 & P. syringae & KY629186 \\
\hline CLD16 & -5 & -5 & P. syringae & KY629187 \\
\hline CLD17 & -5 & -5 & P. syringae & KY629188 \\
\hline CLD18 & -5 & -5 & P. syringae & KY629189 \\
\hline CLD19 & -6 & -5 & P. syringae & KY629190 \\
\hline CLD20 & -6 & -5 & P. syringae & KY629191 \\
\hline CLD21 & -5 & -5 & P. syringae & KY629192 \\
\hline CLD22 & -6 & -6 & P. syringae & KY629193 \\
\hline CLD23 & -6 & -6 & P. syringae & KY629194 \\
\hline CLD24 & -6 & -6 & P. plecoglossicida & KY629195 \\
\hline CLD25 & -6 & -6 & P. syringae & KY629196 \\
\hline CLD26 & -6 & -6 & P. syringae & KY629197 \\
\hline CLD27 & -5 & -5 & P. syringae & KY629198 \\
\hline CLD28 & -5 & -5 & P. syringae & KY629199 \\
\hline CLD29 & -11 & -11 & P. syringae & KY629200 \\
\hline CLD30 & -5 & -5 & P. syringae & KY629201 \\
\hline CLD31 & -5 & -5 & Pseudomonas & KY629202 \\
\hline CLD32 & -5 & -5 & P. syringae & - \\
\hline CLD33 & -11 & -11 & P. fragi & - \\
\hline CLD34 & -11 & -10 & P. syringae & KY629203 \\
\hline CLD35 & -9 & -9 & Pseudomonas & - \\
\hline CLD36 & -6 & -6 & P. syringae & KY629204 \\
\hline CLD37 & -6 & -5 & P. syringae & KY629205/206 \\
\hline CLE1 & -12 & -11 & P. fragi & - \\
\hline
\end{tabular}

(Continued)
TABLE 4 | Continued

\begin{tabular}{|c|c|c|c|c|}
\hline Strain ID & $\begin{array}{c}\text { Freezing temp } \\
\text { of droplet \#1 } \\
\left({ }^{\circ} \mathrm{C}\right)\end{array}$ & $\begin{array}{c}\text { Freezing temp } \\
\text { of droplet \#2 } \\
\left({ }^{\circ} \mathrm{C}\right)\end{array}$ & Sequence ID & Gen Bank \# \\
\hline CLE2 & -8 & -10 & P. fragi & - \\
\hline CLE3 & -5 & -5 & P. syringae & KY629207 \\
\hline CLE4 & -10 & -10 & P. syringae & KY629208 \\
\hline CLE5 & -8 & -10 & P. fragi & - \\
\hline CLE6 & -6 & -6 & P. syringae & KY629209 \\
\hline CLE7 & -5 & -5 & Pseudomonas & - \\
\hline CLE8 & -12 & -7 & P. fragi & - \\
\hline CLE9 & -5 & -5 & P. viridiflava & - \\
\hline CLE10 & -5 & -5 & P. fragi & - \\
\hline CLE11 & -5 & -5 & P. syringae & KY629210 \\
\hline CLE12 & -5 & -12 & P. syringae & KY629211 \\
\hline CLE13 & -5 & -5 & P. syringae & KY629212 \\
\hline CLE14 & -10 & -10 & Pseudomonas & - \\
\hline CLE15 & -10 & -10 & Pseudomonas & - \\
\hline CLE16 & -7 & -5 & Pseudomonas & - \\
\hline CLE17 & -12 & -12 & Pseudomonas & - \\
\hline CLE18 & -10 & -10 & P. fragi & - \\
\hline CLE19 & -5 & -5 & P. syringae & KY629213 \\
\hline CLE20 & -8 & -10 & P. syringae & KY629214 \\
\hline CLE21 & -5 & -5 & P. syringae & KY629215 \\
\hline CLE22 & -5 & -5 & P. syringae & KY629216 \\
\hline CLE23 & -10 & -10 & P. syringae & KY629217 \\
\hline CLE24 & -5 & -5 & P. syringae & KY629218 \\
\hline CLE25 & -5 & -5 & P. syringae & KY629219 \\
\hline CLE26 & -5 & -5 & P. syringae & KY629220 \\
\hline CLF1 & -5 & -5 & P. syringae & KY629221 \\
\hline CLF2 & -5 & -5 & P. syringae & KY629222 \\
\hline CLF3 & -9 & -9 & P. syringae & KY629223 \\
\hline CLG1 & -5 & -5 & P. syringae & KY629224 \\
\hline CLG2 & -5 & -5 & Pseudomonas & - \\
\hline CLI1 & -7 & -10 & P. syringae & KY629225 \\
\hline
\end{tabular}

CLA, November 2015; CLB, 18 November 2015; CLC, 16 December 2015; CLD, 21 January 2016; CLE, 4 February 2016; CLF, 2 May 2016; CLG, 16 May 2016; CLI, 7 June 2016.

moving within and among these environments have not yet been conducted. There was a significant difference between the percent of Ice + strains in the fall collections and spring collections $(P<$ $0.001)$. The five fall/winter collections had a higher frequency of Ice+ bacteria ranging from 6 to $15 \%$ while the spring collections had a frequency of $0-2 \%$. This significant difference between these collections suggests a potential ecological role for the ice nucleation phenotype; Ice+ strains of $P$. syringae may be better adapted to colder climates.

Strains of Ice $+P$. syringae were identified from diverse phylogroups. Berge et al. (2014) conducted phylogenetic analysis using 4 housekeeping genes from 763 strains of $P$. syringae and found that using only the cts gene sequence was a reliable and efficient method of classifying P. syringae. Berge et al. (2014) examined the phenotypic and genetic characteristics of strains of P. syringae within each of 13 phylogroups. Many of the strains 


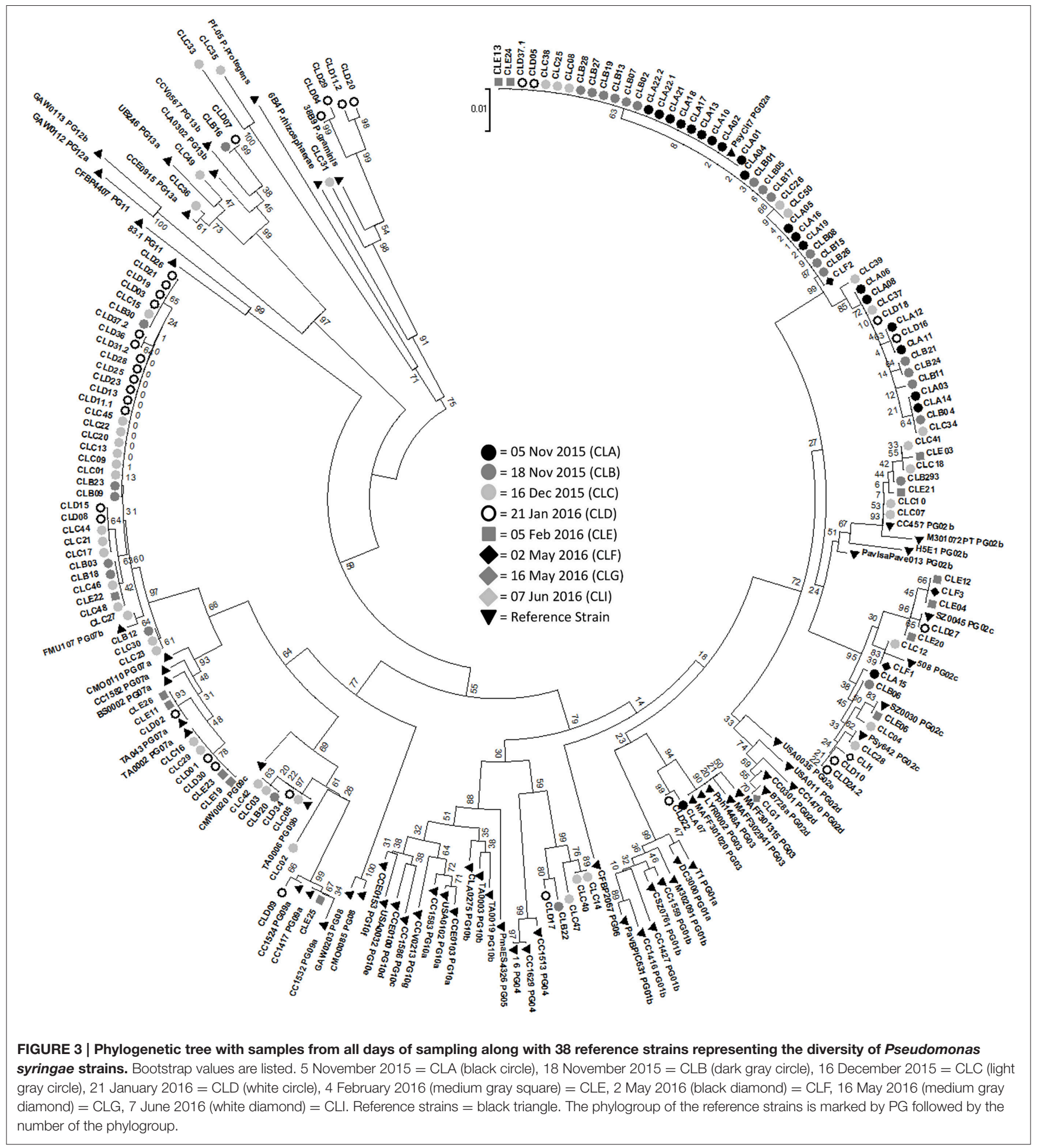

from Claytor Lake were in phylogroup 2, which is the most widespread phylogroup found in all habitats studied with around $85 \%$ of the strains previously sampled being Ice+ (Morris et al., 2010). Two strains were in phylogroup 3, which includes many crop pathogens although few strains from this phylogroup have been found in the environment perhaps due to competition from faster growing strains (Monteil et al., 2014). About 20\% of previously sampled phylogroup 3 strains were Ice+ (Berge et al., 2014). Five strains may be in phylogroup 4, although there was weak bootstrap support for this grouping at only 60. All strains previously reported in phylogroup 4 have been Ice + although these strains are rarely detected in the environment (Berge et al., 
2014). Many of the strains from Claytor Lake were in phylogroup 7 , which includes strains previously identified as $P$. viridiflava (Berge et al., 2014). These strains have been commonly found in environmental reservoirs with about $45 \%$ being Ice+ (Berge et al., 2014). We found 7 strains in phylogroup 9. All previous strains in phylogroup 9 have been found in aquatic habitats, but only $4 \%$ have been Ice+ (Berge et al., 2014). Berge et al. (2014) reported none of the samples in phylogroups $8,11,12$, and 13 showed Ice+ activity. Since we sequenced the $c t$ sene only for Ice + strains, it is not surprising that none of the strains we collected were in these phylogroups, with the exception of phylogroup 13 to which four of our isolates belonged. We also examined the distribution of strains in different phylogroups according to sampling depth and found there was no correlation between sampling depth and phylogroups. All of the samples from the spring collections were in phylogroup 2, although the spring collections had so few Ice+ strains that it was difficult to examine their diversity.

A majority of the Pseudomonas Ice + strains were P. syringae, which is consistent with previous studies indicating $P$. syringae is the most wide spread biological ice nucleator (Fall and Fall, 1998; Morris et al., 2011; Murray et al., 2012). Many of the non$P$. syringae colonies showed the highest match with $P$. fluorescens when blasted against the NCBI database. P. fluorescens has previously been reported to have the Ice+ phenotype as well (Warren and Corotto, 1989).

This study indicates that freshwater lakes may be significant reservoirs of Ice $+P$. syringae. Future work should examine the abiotic and biotic factors driving the potential selection of icenucleating strains of $P$. syringae in freshwater systems. Bacteria at or near the surface of lakes have the potential to aerosolize through crashing waves, wind sweeping across the surface of the water, and via rainsplash. Bacteria at greater depths within lakes also have the potential to move to the surface; strains of $P$. syringae contain flagella and may swim short distances and/or be moved through currents and seasonal turnover. Spring and

\section{REFERENCES}

Berge, O., Monteil, C. L., Bartoli, C., Chandeysson, C., Guilbaud, C., Sands, D. C., et al. (2014). A user's guide to a data base of the diversity of Pseudomonas syringae and its application to classifying strains in this phylogenetic complex. PLoS ONE 9:e105547. doi: 10.1371/journal.pone.0105547

Briée, C., Moreira, D., and López-García, P. (2007). Archaeal and bacterial community composition of sediment and plankton from a suboxic freshwater pond. Res. Microbiol. 158, 213-227. doi: 10.1016/j.resmic.2006.12.012

Cochet, N., and Widehem, P. (2000). Ice crystallization by Pseudomonas syringae. Appl. Microbiol. Biotechnol. 54, 153-161. doi: 10.1007/s002530000377

Comeau, A. M., Harding, T., Galand, P. E., Vincent, W. F., and Lovejoy, C. (2012). Vertical distribution of microbial communities in a perennially stratified Arctic lake with saline, anoxic bottom waters. Sci. Rep. 2:604. doi: 10.1038/srep00604

Elliott, C. (1951). Manual of Bacterial Plant Pathogens. Waltham, MA.

Fall, A. L., and Fall, R. (1998). High-level expression of ice nuclei in Erwinia herbicola is induced by phosphate starvation and low temperature. Curr. Microbiol. 36, 370-376. doi: 10.1007/s002849900325

Glöckner, F. O., Zaichikov, E., Belkova, N., Denissova, L., Pernthaler, J., Pernthaler, A., et al. (2000). Comparative 16S rRNA analysis of lake bacterioplankton reveals globally distributed phylogenetic clusters including fall turnover creates mixing throughout all the vertical profile of the lake that can bring new bacteria to the surface. Consequently, these bacteria have the potential to move to other parts of the water cycle and into the atmosphere (Morris et al., 2008), and future work should also focus on the processes involved in the aerosolization of these strains from aquatic environments.

\section{AUTHOR CONTRIBUTIONS}

RP: designed and conducted experiments, analyzed data, and led the writing of the manuscript. BV: advised the experiment design and provided technical advice related to the sequencing, analyzed data, and assisted in writing the manuscript. DS: managed the project, designed experiments, assisted with sample collection, analyzed data, and assisted in writing the manuscript.

\section{FUNDING}

This research was supported in part by the National Science Foundation (NSF) under Grant Numbers DEB-1241068 [Dimensions: Collaborative Research: Research on Airborne Ice-Nucleating Species (RAINS)] and DGE-0966125 [IGERT: MultiScale Transport in Environmental and Physiological Systems (MultiSTEPS)]. Any opinions, findings, and conclusions or recommendations expressed in this material are those of the authors and do not necessarily reflect the views of the National Science Foundation.

\section{ACKNOWLEDGMENTS}

We thank Regina Hanlon and Kevin Failor for their technical expertise, Andrew Kniowski for his help with statistics, and Gunjune Kim for his assistance in analyzing the phylogenetic data. We thank Bryan Brown for use of the Van Dorn sampler, and we thank Christopher Anderson, Ray David, and Ammar Motorwala for their assistance in collecting samples. an abundant group of actinobacteria. Appl. Environ. Microbiol. 66, 5053-5065. doi: 10.1128/AEM.66.11.5053-5065.2000

Haglund, A.-L., Lantz, P., Törnblom, E., and Tranvik, L. (2003). Depth distribution of active bacteria and bacterial activity in lake sediment. FEMS Microbiol. Ecol. 46, 31-38. doi: 10.1016/S0168-6496(03)00190-9

Hiorns, W. D., Methe, B. A., Nierzwicki-Bauer, S. A., and Zehr, J. P. (1997). Bacterial diversity in Adirondack mountain lakes as revealed by $16 \mathrm{~S}$ rRNA gene sequences. Appl. Environ. Microbiol. 63, 2957-2960.

Joly, M., Attard, E., Sancelme, M., Deguillaume, L., Guilbaud, C., Morris, C. E., et al. (2013). Ice nucleation activity of bacteria isolated from cloud water. Atmos. Environ. 70, 392-400. doi: 10.1016/j.atmosenv.2013. 01.027

Lindow, S. (1983). The role of bacterial ice nucleation in frost injury to plants. Annu. Rev. Phytopathol. 21, 363-384. doi: 10.1146/annurev.py.21.090183. 002051

McDonough, R. J., Sanders, R. W., Porter, K. G., and Kirchman, D. L. (1986). Depth distribution of bacterial production in a stratified lake with an anoxic hypolimnion. Appl. Environ. Microbiol. 52, 992-1000.

Mohan, S., and Schaad, N. (1987). An improved agar plating assay for detecting Pseudomonas syringae pv. syringae and $P$. s. pv. phaseolicola in contaminated bean seed. Phytopathology 77, 1390-1395. doi: 10.1094/Phyto-77-1390 
Monteil, C. L., Bardin, M., and Morris, C. E. (2014). Features of air masses associated with the deposition of Pseudomonas syringae and Botrytis cinerea by rain and snowfall. ISME J. 8, 2290-2304. doi: 10.1038/ismej.2014.55

Monteil, C. L., Guilbaud, C., Glaux, C., Lafolie, F., Soubeyrand, S., and Morris, C. E. (2012). Emigration of the plant pathogen Pseudomonas syringae from leaf litter contributes to its population dynamics in alpine snowpack. Environ. Microbiol. 14, 2099-2112. doi: 10.1111/j.1462-2920.2011.02680.x

Monteil, C. L., Rongman, C., Liu, H., Mechan Llontop, M. E., Leman, S., Studholme, D. J., et al. (2013). Nonagricultural reservoirs contribute to emergence and evolution of Pseudomonas syringae crop pathogens. New Phytologist. 199, 800-811. doi: 10.1111/nph12316

Monteil, C. L., Yahara, K., Studholme, D. J., Mageiros, L., Méric, G., Swingle, B., et al. (2016). Population-genomic insights into emergence, crop adaptation and dissemination of Pseudomonas syringae pathogens. Microbial. Genomics. 2, 1-16. doi: 10.1099/mgen.0.000089

Morris, C. E., Conen, F., Alex Huffman, J., Phillips, V., Pöschl, U., and Sands, D. C. (2014). Bioprecipitation: a feedback cycle linking Earth history, ecosystem dynamics and land use through biological ice nucleators in the atmosphere. Glob. Chang. Biol. 20, 341-351. doi: 10.1111/gcb.12447

Morris, C. E., Kinkel, L. L., Xiao, K., Prior, P., and Sands, D. C. (2007). Surprising niche for the plant pathogen Pseudomonas syringae. Infect. Genet. Evol. 7, 84-92. doi: 10.1016/j.meegid.2006.05.002

Morris, C. E., Monteil, C. L., and Berge, O. (2013). The life history of Pseudomonas syringae: linking agriculture to earth system processes. Annu. Rev. Phytopathol. 51, 85-104. doi: 10.1146/annurev-phyto-082712-102402

Morris, C. E., Sands, D. C., Vinatzer, B. A., Glaux, C., Guilbaud, C., Buffiere, A., et al. (2008). The life history of the plant pathogen Pseudomonas syringae is linked to the water cycle. ISME J. 2, 321-334. doi: 10.1038/ismej.2007.113

Morris, C., Sands, D., Bardin, M., Jaenicke, R., Vogel, B., Leyronas, C., et al. (2011). Microbiology and atmospheric processes: research challenges concerning the impact of airborne micro-organisms on the atmosphere and climate. Biogeosciences 8, 17-25. doi: 10.5194/bg-8-17-2011

Morris, C., Sands, D., Vanneste, J., Montarry, J., Oakley, B., Guilbaud, C., et al. (2010). Inferring the evolutionary history of the plant pathogen Pseudomonas syringae from its biogeography in headwaters of rivers in North America, Europe, and New Zealand. MBio 1, e00107-e00110. doi: $10.1128 / \mathrm{mBio} .00107-10$

Moukahel, A.-A., Asaad, S., Debbes, B., Morris, C. E., and Sands, D. C. (2015). Characterization of wheat genotypes as sources of ice nucleation active bacteria for bioprecipitation aerosols. Int. J. Phytopathol. 4, 63-72. Available online at: http://escijournals.net/index.php/phytopath/ article/view/ijpp1179/pdf1179

Murray, B., O’Sullivan, D., Atkinson, J., and Webb, M. (2012). Ice nucleation by particles immersed in supercooled cloud droplets. Chem. Soc. Rev. 41, 6519-6554. doi: 10.1039/c2cs35200a
Nemecek-Marshall, M., Laduca, R., and Fall, R. (1993). High-level expression of ice nuclei in a Pseudomonas syringae strain is induced by nutrient limitation and low temperature. J. Bacteriol. 175, 4062-4070. doi: 10.1128/jb.175.13.4062-4070.1993

Pietsch, R. B., David, R. F., Marr, L. C., Vinatzer, B., and Schmale, D. G. III. (2015). Aerosolization of two strains (Ice+ and Ice-) of Pseudomonas syringae in a collison nebulizer at different temperatures. Aerosol Sci. Technol. 49, 159-166. doi: 10.1080/02786826.2015.1010636

Renard, P., Canet, I., Sancelme, M., Wirgot, N., Deguillaume, L., and Delort, A.-M. (2016). Screening of cloud microorganisms isolated at the Puy de Dôme (France) station for the production of biosurfactants. Atmos. Chem. Phys. 16, 12347-12358. doi: 10.5194/acp-16-12347-2016

Sands, D., Langhans, V., Scharen, A., and de Smet, G. (1982). The association between bacteria and rain and possible resultant meteorological implications. Idojaras. J. Hungarian Meteorol. Serv. 86, 148-152.

Tamaki, H., Sekiguchi, Y., Hanada, S., Nakamura, K., Nomura, N., Matsumura, M., et al. (2005). Comparative analysis of bacterial diversity in freshwater sediment of a shallow eutrophic lake by molecular and improved cultivation-based techniques. Appl. Environ. Microbiol. 71, 2162-2169. doi: 10.1128/AEM.71.4.2162-2169.2005

Vaïtilingom, M., Attard, E., Gaiani, N., Sancelme, M., Deguillaume, L., Flossmann, A. I., et al. (2012). Long-term features of cloud microbiology at the puy de Dôme (France). Atmos. Environ. 56, 88-100. doi: 10.1016/j.atmosenv.2012.03.072

Wang, Y., Sheng, H.-F., He, Y., Wu, J.-Y., Jiang, Y.-X. Tam, N. F., et al. (2012) Comparison of the levels of bacterial diversity in freshwater, intertidal wetland, and marine sediments by using millions of illumina tags. Appl. Environ. Microbiol. 78, 8264-8271. doi: 10.1128/AEM.01821-12

Warren, G., and Corotto, L. (1989). The consensus sequence of ice nucleation proteins from Erwinia herbicola, Pseudomonas fluorescens and Pseudomonas syringae. Gene. 85, 239-242. doi: 10.1016/0378-1119(89)90488-5

Ye, W., Liu, X., Lin, S., Tan, J., Pan, J., Li, D., et al. (2009). The vertical distribution of bacterial and archaeal communities in the water and sediment of Lake Taihu. FEMS Microbiol. Ecol. 70, 263-276. doi: 10.1111/j.1574-6941.2009.00761.x

Conflict of Interest Statement: The authors declare that the research was conducted in the absence of any commercial or financial relationships that could be construed as a potential conflict of interest.

Copyright (c) 2017 Pietsch, Vinatzer and Schmale. This is an open-access article distributed under the terms of the Creative Commons Attribution License (CC BY). The use, distribution or reproduction in other forums is permitted, provided the original author(s) or licensor are credited and that the original publication in this journal is cited, in accordance with accepted academic practice. No use, distribution or reproduction is permitted which does not comply with these terms. 